The Influence of Relative Sea Level Variation on Depositional Settings of the Late Jurassic Arab Formation in a Giant Gas Field, United Arab

Emirates

D. Green* (Badley Ashton \& Associates, UK), D.A. Lawrence (Al Hosn Gas, UAE) \& M. Al Mansouri (Al Hosn Gas, UAE)

For abstract, PTO

No full paper available 


\title{
15116 The influence of relative sea-level variation on depositional settings of the Late Jurassic Arab Formation in a giant gas field, United Arab Emirates
}

\author{
David Green (Badley Ashton \& Associates < davidgreen@badley-ashton.co.uk >), \\ Mohamed Al Mansouri (Al Hosn Gas) and David Lawrence (Al Hosn Gas)
}

Detailed core description of multiple wells within a giant gas field in the United Arab Emirates (UAE) has enhanced the understanding of the depositional make-up and possible controls on depositional style for the Arab Formation. In this field, the Arab Formation differs from other areas such as Qatar in that anhydrite and dolomite are scarce in the lower units of the Arab Formation and recognition of any sequence-stratigraphic boundaries is limited. In summary, the limestone-dominated reservoir units combine to reflect a large-scale shallowing-upwards trend from basinal/outer, mid-ramp to inner-ramp depositional settings, based on core-derived facies association analysis. The facies associations are defined according to sedimentological and faunal characteristics and form genetically related, largerscale units reflecting a low-energy, mid- to outer-ramp depositional setting, which grades sharply into an inner-ramp shoal and shoal complex depositional setting.

Within the low-energy units of the lowest Arab Formation reservoir, mudstones are interbedded with bioclast-rich accumulations of variable thickness and an uncertain origin. The vertical spacing of these units may be a function of random/non-random cyclicity (?Milankovitch) and reflect variation in depositional slope angle and hence slump/debrite deposits or deeper-water faunal communities. The transition from the distal depositional setting to the proximal depositional setting occurs over a relatively narrow zone into oolitic grainstones as the system progrades. The grainstones form a thick sequence of bedded units reflecting both shoal and intershoal areas within an inner-ramp depositional setting, but cyclicity is not apparent in this interval.

The small-scale cyclicity present in the lower units of the Arab Formation may potentially be equal to those that are defined by dolomite-anhydrite cycles in Qatar, but in this area of Abu Dhabi, the overall distal setting has negated the development of these mixed evaporite-carbonate cycles. The implications of this include a lack of intraformational seals and a uniformity of lithofacies (i.e. limited variation), which is also expressed in the more proximal inner ramp deposits and provides for good reservoir potential. 